https://helda.helsinki.fi

\title{
Death and the Transcendental Subject
}

\section{Pihlström, Sami Johannes}

2016

Pihlström , S J 2016 , ' Death and the Transcendental Subject ' , Idealistic Studies , vol. 46 , no. 3 , pp. 323-339 . https://doi.org/10.5840/idstudies201882272

http://hdl.handle.net/10138/255639

https://doi.org/10.5840/idstudies201882272

cc_by_nc_sa

acceptedVersion

Downloaded from Helda, University of Helsinki institutional repository.

This is an electronic reprint of the original article.

This reprint may differ from the original in pagination and typographic detail.

Please cite the original version. 


\title{
DEATH AND THE TRANSCENDENTAL SUBJECT
}

\section{Sami Pihlström}

University of Helsinki, Finland

\section{sami.pihlstrom@helsinki.fi}

\begin{abstract}
This paper discusses the philosophy of death and mortality from a transcendental perspective. I first criticize the metaphysically realistic background assumptions of mainstream analytic approaches to the philosophy of death. Secondly, I defend a transcendentally idealistic approach, drawing attention to how the topic of death can be illuminated by means of the notion of the transcendental subject. Thirdly, I identify a problem in this approach: the transcendental subject needs to recognize its own mortality. Fourthly, I propose a pragmatist way out of this problem. This, however, is no way out of the general issue that mortality as a structural element of the human condition provides us with. Rather, pragmatism (joining forces with transcendental philosophy) can show us a way of living with this condition. ${ }^{1}$
\end{abstract}

\section{Introduction: Metaphysical realism and "third-personal" approaches to death and mortality}

The naturalistic mainstream approaches in contemporary metaphysics of death, as well as their applications to ethical issues of death and dying, ${ }^{2}$ are based on a metaphysically realistic understanding of the relation between the self and the world. D eaths, according to this picture, are simply natural events in the natural world; my own death is no exception. Death, dying, and mortality are viewed from an objective, "third-personal", or even theocentric perspective, a "God's-Eye-View". This presupposes a broadly "Aristotelian" conception of metaphysics as a general category theory; death and the mortal subject fall in their place in the categorial structure of reality. The world in which human selves live and 
die has its "own" ontological structure independently of those selves and their experiential and worldconceptualizing or -categorizing perspectives. ${ }^{3}$

I will not criticize Aristotelian conceptions of metaphysics in general. What I will draw attention to is the frustrating irrelevance of contemporary philosophy of death and mortality based on analytic metaphysics. Such philosophy of death does not seem to be able to say anything about the human relevance of death, dying, and mortality. It does not seem to address the ways in which these features of the human condition are both metaphysically and ethically significant to us.

Consider an analogy. Analytic philosophy of death can be compared to analytic philosophy of religion, especially the discourse on theodicy. This comparison is illuminating not because these two discourses would share the same metaphysical views - which they do not, as analytic philosophy of death is typically atheistic and naturalistic, while analytic theodicy arguments are typically theistic ${ }^{4}$ - but because both are irrelevant to the human attempt to live ("toward death") through our mortal lives that are often full of suffering. When an analytic metaphysician speaks about the metaphysics of resurrection based on, e.g., an "animalist" theory of a "remnant" of a human being that will be preserved by God between someone's death and their resurrection, or the possible moral reasons G od might have for allowing an atrocity such as the Holocaust to take place, one can hardly take these as much more than cruel jokes.

To take another example, consider the debates over the harmfulness of death and the question of whether it would be desirable to be immortal. This dispute on the "tedium" of immortality also ignores the transcendental level of inquiry, hence ignoring the fundamental difference between our form(s) of life and that of the imagined immortals that couldn't die. The parties to such a debate uncritically help themselves to the entirely unsupported assumption that our concepts of interest, virtue, or meaning(fulness) would be available to immortals whose lives would be completely different from ours. It requires only a modest dose of late-Wittgensteinian therapy to note that such an availability assumption is unfounded. Insofar as the meaning of concepts is rooted in forms of life, we cannot imagine what the relevant concepts would mean for the "immortals" postulated for the sake of hypothesis, and we are entirely at a loss to 
say whether their lives would be tedious or non-tedious, or whether such a distinction would be applicable to them at all. The immortals would not have the concepts we do, simply because their lives would be entirely alien to ours. They would hardly even have a concept of personal identity in the sense we do; nor could we understand what, say, moral virtues or intellectual achievements would mean for them (or for us, if our lives were infinite). We can only try to imagine such things from within our own mortal condition, which is, presumably, both a blessing and a curse.

We are, then, unable to determine whether the imagined immortal life would be desirable for us, as our lives lack the concept of desirability that would be available to them, and vice versa. In Jonathan Lear's terms, our way of being "minded" is completely different from theirs; ${ }^{5}$ we could as little understand the immortals as we could understand Wittgenstein's speaking lion. It is hubristic to suppose that we could, from the perspective of our form of life structured by finitude and mortality, make any considered judgments here. This hubris follows from the failure to approach the issue transcendentally, from within the mortal condition itself. In contrast to the "first-order" question concerning the supposed tedium of immortality, or lack thereof, the relevant question opening up in a transcendental reflection is a "secondorder" one: the finitude entailed by our mortality is necessary for the possibility of asking whether our lives are meaningful or meaningless, or inquiring into any possible meaningfulness or meaninglessness in life. Mortality makes these questions "urgent" to us even if it may also make it impossible to answer them in any definite way; even more importantly, it makes them possible questions for us to pursue.

Furthermore, consider the welfare comparison calculations presented in the discussions concerning the harmfulness of death. These are, it seems to me, as much a parody of the "harm" of death manifested in the horror and anxiety we experience when reflecting on our mortal condition as theodicist speculations about God's possible moral reasons for allowing suffering are both comic and terrible from the perspective of the sufferer. ${ }^{6}$ The precise nature of the irrelevance of analytic philosophy of death can be demonstrated by taking a look at how a very different kind of approach, a "first-personal" one, can lead to philosophical discoveries that are unavailable in the "third-personal" approaches. The main reason for 
the irrelevance of mainstream (realistic) metaphysics of death is, precisely, the fact that it treats my death and the deaths of others symmetrically. The fundamental asymmetry we need to deal with here is only visible from a transcendental point of view.

\section{Transcendental solipsism and the transcendental subject}

The kind of explorations of death we find in the analytic, metaphysically realistic mainstream described above would, from a Kantian perspective (in contrast to the "Aristotelian" one), amount to little more than transcendental illusion, Schwärmerei. ${ }^{7}$ The problem with the approaches in this paradigm is that they are non-transcendental, presupposing a theocentric perspective ignoring the need to examine the significance of death from a "first-personal" standpoint. The attempt to occupy the unattainable theocentric perspective of metaphysical realism is the proton pseudos of the approaches I am criticizing. We should replace such a misguided approach by a resolutely anthropocentric perspective on human mortality, exemplified by transcendental philosophies of death, invoking the notion of a transcendental subject. ${ }^{8}$ Insofar as we adopt such an anthropocentric perspective, we will examine human mortality "from within" the condition it defines and irreducibly shapes and structures - that is, reflexively and first-personally, not in an imagined objective way "from above". This move from theocentrism to anthropocentrism can be metaphilosophically motivated on the basis of pragmatism seeking to emphasize the need to make the philosophy of death humanly relevant. ${ }^{9}$

This is not merely a matter of a pragmatic need. The unattainability of the "God's-Eye-View" is not a contingent limitation of the human condition but a necessary transcendental limit; however, this is something that can be shown or even meaningfully discussed - transcendentally - only from within the anthropocentric perspective itself, that is, only when we have left behind the futile attempt to occupy the theocentric perspective. This can be seen as an analogy to Kant's distinction between appearances and things in themselves: it is only from the standpoint of Kant's critical idealism that this distinction - qua transcendental - arises. If you haven't adopted that standpoint, you will uncritically believe that 
appearances are things in themselves. That distinction will be available to you only when you have adopted the transcendental perspective. Moreover, adopting that perspective will, according to Kant, enable us to get rid of metaphysical problems that haunt us if we stick to the desperate attempt to view the world theocentrically, such as the antinomies. Such considerations provide independent support for the transcendental approach (but cannot be considered here).

In general, what it means to adopt a transcendental approach to anything, including death and mortality, is not easily definable, as there are different types of transcendental philosophy available. What I primarily mean by adopting a transcendental approach can be stated by emphasizing five interconnected, familyresemblancelike features of transcendental reflection (understood in a broader sense than mere "transcendental argumentation" cashed out in familiar argument schemas). Such an inquiry (i) is concerned with neeessary conditions for the possibility of certain (humanly given, hence actual) phenomena, something whose possibility is taken for granted; (ii) by examining such conditions sets limits to those conditioned phenomena and hence to human possibilities; (iii) engages in a reflexive examination of phenomena that are only available from within those limits and on the basis of those conditions; (iv) shows how the relevant phenomena are constituted by the transcendental structures of the relevant conditions; and (v) locates the source of such constitutivity in the activity of the transcendental subjed (possibly reconceptualized, or even "naturalized"). For example, a late-Wittgensteinian version of such transcendental inquiry would be concerned with the necessary conditions for the possibility of linguistic meaning, would examine the limits of meaning as the limits of what can be said and done within languagegames, would examine meaning and its limits and conditions reflexively from within a human form of life in which meaning is always already taken for granted, would show how the possibility of meaning is constituted by our practical engagement in language-games ("meaning is use"), and would reinterpret the meaning- and world-constituting transcendental self as a social subject engaging in language-use within a form of life. In any such transcendental inquiry, neither meaning, experience, nor the experienceable world is just "given" to us in a metaphysically innocent form. 
The metaphysically realistic understanding of death - or of the world in which subjects live and in which their deaths take place - must therefore be contrasted with a transcendentally idealistic position, according to which the world is transcendentally dependent on, or constituted by, the structures of subjectivity. D eath is, from a transcendental perspective, an (or, better, the) end of the world rather than simply an event in the world or something that could be experienced as part of one's life and whose harmfulness could be rationally discussed in the way we may discuss the harmfulness of, say, having a headache or being run over by a bicycle. This is, roughly, how Wittgenstein formulates the matter in the Tractatus, maintaining that the metaphysical (transcendental) subject is the "limit of the world" instead of being a thing in, or a part of, the world ("die G renze, nicht ein Teil der W elt"). ${ }^{10}$ From a broadly Kantian point of view, the categorial ontological structure of reality, including the structure in terms of which phenomena such as death and dying are categorized, is grounded in activities of the transcendental subject. This seems to hold even if the subject is not ontologically self-standing but is primarily responsible to and for the other in Emmanuel Levinas's sense (and constitutively dependent on this responsibility). Even this primordial ethical relation to another mortal self can be regarded as a transcendental structure of subjectivity, because in the Levinasian picture infinite ethical responsibility is constitutive of my subjectivity; it is something that concems me first and foremost, as I cannot be substituted by anyone else in this responsibility. Arguably there is, then, a kind of methodological solipsism inevitably involved in any transcendental philosophy of death and subjectivity, even when the transcendental inquiry focuses on otherness rather than (in Heideggerian terms) the "mineness" of death. ${ }^{11} \mathrm{On}$ the other hand, from a solipsistic starting point, the intersubjectivity of death and dying, and of the self, must be transcendentally examined as well.

However, it is important to avoid construing the transcendental dependence of the world on the transcendental subject along the lines of any ontological, let alone causal, dependence in any metaphysically realistic sense. The fatal mistake in metaphysical realists' criticisms of transcendental idealism is the assumption that the world and its objective structures would be claimed to be causally or ontologically dependent on, or "made by", the subject. No such thing is, of course, claimed by the 
Kantian or Wittgensteinian transcendental philosopher. It is the very objectivity of the objective world that is constituted by the transcendental activity of the subject. The Kantian transcendental unity of apperception or the Wittgensteinian metaphysical subject as a "limit" of the world cannot be found among the worldly objects whose objectivity and givenness (and linguistic representability) they make possible. The issue of death is fundamental right here precisely because we need to think of the death of this world-constituting subject as the disappearance of the objectivity of the world itself, and of the world, too - a disappearance, however, that paradoxically verges on immortality because death is nothing that could take place in the world. ${ }^{12}$

Reducing transcendental relations of world-constitution to relations of ontological dependence would presuppose that we can practice ontology at a level that is more general and inclusive than the level of transcendental inquiry. However, the very point of engaging in transcendental inquiry is to make ontology (among other things) possible. Our understanding of ontological categories and relations of (in)dependence must itself be grounded in a transcendental analysis of our ability to categorize reality at all. The ontological, in short, must be grounded in the transcendental, rather than the other way round.

The intentional or unintentional misunderstanding of the notion of the transcendental subject - and of the idea of the transcendental generally - has resulted in a lot of confusion in discussions of death and subjectivity. Let us, as an example drawn from contemporary debates, take a look at how J.J. Valberg's theory of death and the self is criticized by Mark Johnston. The recent books by these two philosophers are major contributions to the philosophy of death..$^{13}$

Valberg employs the notion of a personal horizon in his examination of death. It is, he tells us, "only by being 'at the center' of the personal horizon, of the horizon that is 'mine,' that something (a human being) is a 'subject."'14 This horizon, however, is, like the Wittgensteinian subject, "nothing in itself"; it is not among the many horizons there are but "the horizon", ${ }_{15}^{15}$ and this is the "truth in solipsism". This nothingness is a fundamental element of the transcendentality of the horizon. If the horizon were "something", a thing in the world, it would no longer be transcendental (though this is not exactly the 
way Valberg expresses his point). It would not play the constitutive role in making the world possible if it were itself an object or a place in the world.

Things get complicated when Valberg starts to speak about other horizons, all of them claiming "preeminence" for themselves. ${ }^{16}$ "In regarding you as a metaphysical equal, I recognize your horizon as outside my horizon", he says. ${ }^{17}$ But this is precisely what is problematic when we consider death. D eath "in the metaphysical sense" is the "cessation of the crucial subject matter, of my horizon", of "that from within which the world appears" ${ }^{18}$ Valberg argues that "the fact that I will die (in the metaphysical sense) leaves the totality I call 'the world' untouched", because "the fact of death concerns not the ceasing to be of anything in that totality, but the ceasing to be of THIS, the horizon of the totality". ${ }^{19}$ It is right here, then, that solipsism is brought into this picture. My horizon's being "the horizon" makes it "mine". ${ }^{20}$ Therefore, the word "my" in these phrases cannot refer "possessively" to the human being I happen to be. ${ }^{21}$ Valberg - much more explicitly than Wittgenstein - endorses solipsism, albeit in a deliberately paradoxical form saying that "we" (all) know it to be true:

In this way, we are all solipsists. What makes my horizon "mine" is that it is the horizon. [... ] Solipsism is a solution to our problem. [... ] I think we already know it to be true [... ] but we have to become open to what we know. We have, in other words, to discover philosophically this truth that we already know, the truth of solipsism. ${ }^{22}$

It is death that "puts us in touch with the truth of solipsism, our own solipsism, in a way that nothing else does" ${ }^{23}$ Here Valberg considers Wittgenstein's Tractatus, observing that Tractarian solipsism is concerned with the "horizon or limit of the world" ${ }^{24} \mathrm{He}$ interprets the relevant sections of the Tractatus by saying that this horizon - that is, the "self of solipsism" - "is nothing in itself" in the sense that there is no increase in reality whatsoever due to its being internal to that self; the self of solipsism "adds nothing to the world, just as death takes away nothing from the world", though what it does take away is precisely the self of solipsism, the horizon, the limit. ${ }^{25}$ 
In Valberg's terms, death will eliminate all presence; there will be NOTHING. "The world will remain, but there will be NOTHING" - and this cannot be relativized into there being just "NOTHING for me", because "what death means to us" is not any such relativized nothingness but absolute nothingness. ${ }^{26}$ We do not, at death, just lose the world (on the contrary, the world will continue to exist without us, which is also horrifying), but we lose the horizon enabling the world to appear - to be - at all. It is this NOTHING NESS as a complete absence of anything that Valberg believes we inevitably find awful and incomprehensible. ${ }^{27}$ Death is not only awful but in a sense impossible, solipsistically understood. ${ }^{28} \mathrm{~A}$ temptingly easy solution would be to emphasize the mortal other at this point, urging us to take seriously the other's horizon and its existential fragility before our own, but we should remember (as we saw in relation to Levinas) the tendency of solipsism to return: if my horizon collapsed into NOTHING NESS, I would no longer have the other, either, as someone to whom I would be infinitely responsible from within my horizon. The other needs (and, in Levinas's language, "summons") me, and thus my horizon. There are no metaphysical equals here: "I alone face absolute NOTHINGNE SS." ${ }^{29}$

Only toward the end of his rich book does Valberg employ the concept of the transcendental self, which he identifies with the "horizonal self" ${ }^{30}$ The absence of the transcendental self amounts to the absolute nothingness that death is. It is the transcendental self that has, and can have, no metaphysical equals. If it did, it would simply be an object in the world.

Mark Johnston criticizes Valberg's views in his attempt to deal with death and the self. He discusses with references to both the Tradatus and Valberg's book - what he calls the "arena of presence", at the center of which we seem to find ourselves, his version of Valberg's "horizon". Unlike Valberg, he attacks solipsism - and more generally the transcendental considerations of authors like Wittgenstein and Valberg. Y et, the death of a given human being that just happens to be me is different, he says, from my "ownmost" death. I cannot really imagine my ownmost death, as it is the disappearance of the "arena". ${ }^{31}$ The problem is that the transcendental subject cannot just "disappear" from the world like any object, or the empirical subject, can. The disappearance of the transcendental self is, again, the end of the world. 
I am not convinced that Johnston sufficiently appreciates the quite different transcendental consideration of the matter in the T ractatus and in Valberg's study. The transcendental subject - the center of the (my) arena of presence - is not an object of any kind, not even an intentional object, not a thing in the actual world or any possible world, and therefore its end is the end of the (or any) world. Only objects in the world can have identity conditions, not the arena or the world-limiting and world-categorizing self.

While Johnston's discussion comes close to what has been labelled the "no-self" solipsism of the Tractatus, it avoids (question-beggingly) transcendental solipsism. ${ }^{32}$ Here Johnston simply seems to assume (unlike Valberg) that there are many arenas of presence, not just one (mine), and that there is a straightforward sense in which mine could disappear. The problem is whether one can even meaningfully say this, insofar as one starts from transcendental considerations. Wittgenstein's argument is based on a transcendental examination of thenecessary conditions for the possibility of meaning and representation; the result of such an examination is that the world can only be limited by me (my subjectivity) in order to be linguistically representable. In employing his vocabulary of "picking out" as applied to the Tractatus and its metaphysical or transcendental subject - or the arena - Johnston fatally overlooks not only the possibility but the necessity of a truly transcendental treatment of the matter. The subject of the arena cannot be "picked out" from among others. Any picking out will inevitably take place, in Valberg's terms, within the (my) horizon. No horizon can be picked out; there is no meta-horizon within which to do that.

Nevertheless, one of Johnston's crucial ideas (preparing the ground for his overall thesis that in a sense "the good" may literally survive death, because they are not tied to their individual personal identities) is that the arena of presence and one's occupying it are illusory. We are in a way hallucinating that we are in the center of an arena of presence. We are dealing with merely intentional objects here. ${ }^{33}$ Johnston concludes: "The real problem in principle with the idea of the resurrection of the self is that not even G od could re-create this very arena of presence. (The same could be said of your arena of presence.) God could no more do that than he could re-create Macbeth's dagger or any other mere intentional object." ${ }^{\prime 34}$ 
Johnston further argues that the (Buddhist) doctrine of there being no persistent self (anatta) leads to the doctrine of agape, the commandment to take others' interests as one's own. The unreality of the self, allegedly demonstrated by the argument for the illusoriness of the arena of presence, leads to the observation that our identities are relational and relative, "Protean", and this in turn motivates (without logically entailing) the idea that we should take others' interests into account as our own - and that "the good" among us do. "A certain kind of hallucination - that of a container or arena - bounds even our veridical ex perience of the world", Johnston tells us, and therefore "our selves are [...] creatures of the unreal." ${ }^{35}$ The self's importance thus vanishes.

The agape commands us to treat ourselves as if we were arbitrary others, "albeit one whose life one is called to live" 36 - but now, who is this "one"? The transcendental subject all over again? I find Johnston's argument intriguing but ultimately flawed, because it commits the basic "naturalistic fallacy" of all nontranscendental philosophies of the self, presupposing a conception of the self (or its "arena") as an object in a world "ready-made" prior to and independently of the self. Johnston remains a metaphysical realist - though he does not seem to be able to get rid of the transcendental self, either, which leads to a tension at the center of his position.

Indeed, as Valberg puts it, the "naturalizer" - or, in my terminology, the one viewing the self from a naturalistic, metaphysically realistic standpoint - "lacks, philosophically, a grasp of the horizonal conception of the self" ${ }^{\prime 3}$ Lacking such a grasp, we won't get far in the philosophy of death, nor anywhere else. A failure to appreciate the transcendental character of the subject existentially concerned with its mortality leads to absurdities such as the view that one's being able to die only "one's own death" is no more dramatic than one's being able to, say, have only "one's own haircut" or "one's own lunch" instead of (strictly speaking) having anyone else's. In a trivial sense, those things are one's own, too; we all have our own lunches and haircuts rather than others'. But our deaths are our own in a much more pregnant sense - a sense calling for a transcendental, even solipsistic analysis. A failure to take seriously the transcendental dimension of the problem leads to the tendency to view everything - deaths, haircuts, 
lunches - on a par, as belonging to the same empirical nature whose metaphysical structure is fixed independently of our subjective constitutive contribution. When that metaphysically realistic assumption is given up, a considerably enriched picture of the special significance of one's own mortality opens up.

\section{The mortal transcendental subject}

While there are powerful arguments in Kant himself as well as post-Kantian transcendental philosophy, especially phenomenology and (early) Wittgenstein, that can be employed in defending a transcendentally idealistic conception of the (mortal) subject, there is a reflexive problem that needs to be addressed. Even the transcendental philosopher must - in order to take the phenomenon of death seriously, ontologically and ethically - view the subject as genuinely mortal. O therwise the idea that by removing the subject we remove the world itself cannot be made sense of. D eath must be a genuine limit to transcendental subjectivity. (If the transcendental self itself is a limit of the world, then death is, in a not easily articulated sense, the limit of a limit.) In other words, insofar as the transcendental self - far from being any transcendent, otherworldly metaphysical postulation - is an aspect of our own selfhood, of me, and insofar as mortality and the finitude it entails are necessary transcendental structures of my subjectivity, mortality and finitude must be necessary structures of the transcendental self, too.

Arguably, then, the subject, even qua transcendental, must be "natural" (material, embodied), because otherwise its mortality will be sacrificed. The question is whether a transcendental approach to death and mortality, seeking to critically overcome naturalism, can recognize its own dependence on a certain kind of naturalism. This resembles the way in which phenomenological analyses of transcendental subjectivity are inevitably connected with, or even rooted in, the very same natural attitude that the phenomenological method seeks to overcome. The phenomenologist studying subjectivity as something to which (to whom) the world as natural and objective is given, bracketing the positing of the natural world, including the subject as a natural part of the world, must in a sense begin from the natural attitude, seek ing to overcome it from within..$^{38}$ The natural and the phenomenological (transcendental) attitude are reciprocally contained 
in one another; neither is available to us without the other, and the "us" here - the subject to whom these attitudes are available and who must move from one to the other - needs to understand its own character as something (albeit no "thing") that is paradoxically in constant movement between these two poles. Similarly, when we seek to account for death transcendentally, we must understand ourselves as transcendental subjects to whom the world is given in a way that disappears in death - yielding an end of the world in the sense that the very givenness of the world will be eliminated - and simultaneously as empirical parts of the world that are in such a fragile position as mere limits of the world precisely because of their (our) material, bodily vulnerable nature. If we do not take seriously this natural, embodied vulnerability of the transcendental subject (or the fact that bodily vulnerability is a transcendental feature of subjectivity, as a necessary condition for the possibility of the kind of life we find ourselves living), we fail to take seriously the fundamental transcendental outcome of our inquiry, the conception of death as an end of the world. This could be seen as one way of cashing out Wittgenstein's remark on the solipsistic self's shrinking into a point without extension and disappearing into the world (not from the world), yielding the puzzling coincidence of solipsism and realism. ${ }^{39}$

Valberg is concemed with the same interplay between the natural (bodily, dying) and the transcendental I have emphasized:

If right now my brain ceased to function, what would happen? There would be NOTHING. Would the Kantian "subject of the categories" survive the NOTHING NESS that would be consequent upon the shutting down of my brain? Since its being depends causally on certain things happening in my brain, the Kantian subject would cease to be. But here the subject of the categories appears as (in Kant's phrase) "an object of the categories," in particular, as an object of the category of causation. ${ }^{40}$

The causal processes in the natural world leading up to my death would eliminate the world - and there would then be NOTHING, in Valberg's terms. Acknowledging this is to acknowledge the dependence of my transcendental subjectivity ("my horizon") on worldly natural facts. But it is also to acknowledge 
the impossibility of such facts being there in the absence of my (the) horizon, i.e., the transcendental self. There is a tension here, or almost a paradox - a specific death-related feature of the more general "paradox of subjectivity" ${ }^{41}$ - but the chief virtue of Valberg's discussion is that he is locating the fundamental problem we have to deal with as long as we are willing to engage in a transcendental inquiry into mortality. We should avoid the metaphysically realistic naturalization of death and subjectivity into mere objects in the world, but on the other hand we should observe that the transcendental worries regarding finitude and mortality emerging from within our mortal condition already presuppose our taking seriously the naturalistic prospect of the "shutting down of my brain". Transcendental subjectivity is a dimension of our subjectivity, which is the fully natural subjectivity of a world-involving and worldengaging mortal creature.

D oes the natural embeddedness of my subjectivity mean that metaphysical realism - understanding the subject as a part of the world after all, of a world that exists and possesses its "own" ontological structure independently of the subject - returns to the picture? I do not think so. For it is not exactly metaphysical realism that retums. It is only a certain kind of realism compatible with solipsism that is needed here, and that realism is sufficient for maintaining a (non-reductive) form of naturalism compatible with transcendental inquiry. In Kantian-Wittgensteinian terms, we could say that transcendental idealism or solipsism is compatible with, and even required by, empirical realism. ${ }^{42}$ When the transcendental self is challenged to recognize its own dependence on naturalism and thereby its disappearance into the world in a Wittgensteinian sense, it must do this by referring to the ineliminability of the transcendental self, though. It is still me who is challenged to distinguish between the perspectives on myself as a subject and as an object. In this sense, the transcendental self could be seen as a never-ending spiral: its reflexive reflection on its own paradoxical status as both transcendental and natural goes on forever. Death is, then, like an axis around which the spiral circulates. In its reflection on its own double status, the self inevitably reflects on its mortality. 
But who or what is the subject that can (even consider to) choose to view itself either as a subject (transcendentally) or as an object (naturalistically), engaging in the spiral-shaped movement? It can be suggested that it is only in terms of a pragmatic pluralism that the required integration of the naturalist and the transcendental perspectives on the subject and its mortality can succeed. Whether the subject - or its death - is viewed naturalistically or transcendentally depends on our pragmatic perspective of inquiry. In this sense, pragmatism is the primary philosophical commitment here, making possible the transcendental reflexivity needed in the switch of perspective from the transcendental to the natural (empirical) and back again.

It is, moreover, the pragmatist perspective that enables us to say that the transcendental and naturalist approaches to death, dying, and mortality are mutually co-constitutive rather than individually selfsustained. The transcendental analysis of our mortality requires a kind of naturalism, because otherwise the finitude and embodied fragility of the transcendental subject cannot be recognized. But naturalism by itself won't suffice, either, because it fails to ask the transcendental, reflexive question about the existential significance of our mortal condition from within that condition itself and treats the subject as a mere object among others. Pragmatism, then, is needed as a kind of critical "coordinator" of the interplay of transcendental and naturalist philosophical inquiries. The transcendental method ought to be metaphilosophically considered - and coordinated in relation to naturalistic methods - in a pragmatist way.

\section{Immortality and finitude}

Finally, these ideas on death and subjectivity may be briefly compared to the somewhat paradoxical view familiar from Wittgensteinian philosophy of religion, particularly D .Z. Phillips's work, namely, that it is only by fully endorsing the radical mortality and finitude of the self that the notion of immortality can have any religious significance. I am not here engaging in the philosophy of religion, or dealing with 
religious conceptions of immortality or survival, but it is important to note that Phillips's suggestion can also - against his own self-conception - be interpreted as a (pragmatist) transcendental argument. ${ }^{43}$

Phillips maintains that the temporally infinite existence of a metaphysical soul would be no solution to anything. Any supernaturalist metaphysics of survival is based on metaphysical realism all over again. ${ }^{44}$ The transcendental question concerning "immortality" (in an extended and perhaps metaphorical sense) focuses on the meaningfulness vs. meaninglessness of finite human existence characterized by the paradoxical double character of subjectivity and objectivity. True, Phillips does not call his questions or methods "transcendental". Even so, his insightful discussion of the way in which our discourse of the soul becomes "dislocated" can be regarded as an extended transcendental inquiry into the way in which certain conceptual and/ or linguistic meanings become unavailable to us when we move into another language-game, or fail to pay attention to the way a certain language-game is played. The immortality of the soul, Phillips reminds us, cannot be equated with the continued existence of an immaterial "inner substance called 'the soul'" or of a disembodied spirit, and it cannot be about any such metaphysical state of affairs captured by propositionally true or false beliefs. ${ }^{45}$ In contrast, "whatever is meant by the immortality of the soul, it has to do with the eternal destiny of a human being as a whole" ${ }^{46}$ Of course, we may ask where exactly Phillips gets the normative force to judge certain ways of speaking of the soul as misguided "dislocations" - not, surely, from mere empirical observations of factual language-use, nor from any purely a priori transcendental considerations. The only method available seems to be a Wittgensteinian grammatical examination of the ways in which certain language-games, in this case religious ones, "work", how expressions are correctly used within them. It is such examination that proceeds transcendentally, leading to interesting results concerning the phenomena of death and (im)mortality.

We should, according to Phillips, pay careful attention to the way of speaking of the soul that incorporates the idea that "[t]o believe in the immortality of the soul is to want to give one's soul to God"; when the believer says farewell to her/ his life s/ he gives it to G od and thus dies "in G od" ${ }^{47}$ When we take seriously 
such ways of speaking and also the intimate relation between morality and the concern with immortality, ${ }^{48}$ we may appreciate the view that "[t]he most fundamental barrier to a belief in the immortality of the soul is the desire for self-preservation" ${ }^{49}$ When we are concerned with self-preservation, we are unable to say farewell to life - and thus we do not take mortality seriously enough to deserve immortality. Phillips's suggestion to view immortality precisely as its opposite, as a full-blown acceptance of one's finitude and mortality without any concern to preserve one's identity in eternity, may be religiously sophisticated but it is hardly available to an average religious believer who does not seek resources from (transcendental) philosophy of religion and moral philosophy. Phillips's position amounts to a kind of nonanthropocentrism: we are not at the center of the universe, and we should accept this fact. This comes close to the acknowledgment of the mortality of the transcendental self - the limited character of the self that is itself a limit. But even such a non-anthropocentric view on the self and its relation to the world is available to us only from an anthropocentric (transcendental) perspective.

I am not saying that Phillips's view is unproblematic. But if a mortal human being (if $\mathrm{s} / \mathrm{he}$ is a religious believer, and perhaps even if $s$ / he isn't) is able to view her/ his life as being "answerable to God" and thus to place one's own death "in God's hands", to "see one's death as part of the majesty of God's will", 50 then perhaps the transcendental inquiry into the possibilities of meaning available to us in certain language-games has at least served the pragmatic purpose of rendering our deaths more open to some kind of potential significance (which could also be lost). Phillips is in my view committed to something like transcendental pragmatism when he maintains, with Wittgenstein, that "concepts have their life" "only in practice, in what we do". ${ }^{51}$

\section{Conclusion}

I did not raise the Phillipsian-cum-Wittgensteinian issues in the interest of endorsing them as such but because I agree with Phillips that even our concepts of the soul and of immortality may still, in our secular or post-secular age, have interesting possibilities of meaning that are connected with a transcendental 
analysis of our mortal condition. The transcendental approach to mortality must deal with the (moral) hope for immortality as part of that human condition, and in doing so it must, again, start from within our mortality itself, pragmatically switching between the transcendental and the natural. It is only within mortality that the hope for immortality can become an issue for us.

In a reflexive undertaking of investigating the human condition, certain transcendental insights into that condition may become manifest, or we may become open to them, analogously to the way in which Valberg suggests that we should become open to philosophical discoveries (as well as, inevitably, tensions) concerning, for example, the horizon and the truth of solipsism - without supposing that any specific arguments could "establish the existence of the horizonal subject matter" ${ }^{52}$ I view my own argumentation as an attempt to indicate a way of becoming open to some interesting movements in (actual or possible) philosophical thinking about the human condition. This is, methodologically, very different from mainstream analytic philosophy's unshaking belief in the superiority of the strongest argument. In the philosophical attempt to live with our mortality, such a faith, ignoring the (pragmatist) contextualization of even the most theoretical arguments in practical and existential circumstances of human life, may be most pernicious.

\section{Notes}

\footnotetext{
${ }_{1}^{1}$ For a comprehensive discussion of these topics along related lines, see Sami Pihlström, D eath and Finitude: Toward a Pragmatic Transcendental A nthropology of $\mathrm{H}$ uman L imits and M ortality (Lanham, MD : Lexington Books, 2016).

2 For a summary of relevant recent literature, see Steven Luper, "D eath", Stanford E noydopedia of Philosophy (2002, revised 2014), http:/ / plato.stanford.edu/ entries/ death/. See also Luper, The Philosophy of D eath (Cambridge: Cambridge University Press, 2009).

3 I cannot define metaphysical realism here. However, as a loose characterization we may refer to Hilary Putnam's account of metaphysical realism as the view that the world consists of a definite set of mind-independent objects and properties that can in principle be described from an absolute perspective; truth, in this picture, is non-epistemic correspondence between truthbearers and the mind-independent world. See Putnam, Reason, Truth and H istory (Cambridge: Cambridge University Press, 1981), chapter 3.

4 There are, however, analytic philosophers of death and dying who defend supernaturalist views on immortality and resurrection. Often those same philosophers defend theodicies. For a treatment of analytic metaphysics of resurrection, see Friedrich Hermanni, M etaphysik: E in V ersuch über die letzten F ragen (Tübingen: Mohr-Siebeck, 2011), chapter 6.

5 Jonathan Lear, 0 pen Minded: W orking 0 ut the L ogic of the Soul (Cambridge, MA and London: Harvard University Press, 1986), chapters 11-12.

6 On theodicies as comic and terrible, see D.Z. Phillips, Wittgenstein and Religion (Basingstoke: Palgrave, 2005; first published 1993), 155.
} 
7 I am calling my perspective "Kantian" because it was Kant who inaugurated the transcendental tradition of inquiry. Kant himself defended the immortality of the soul as a postulate of practical reason, while maintaining that there can be no speculative metaphysical knowledge about immortality. I am not making any historical interpretive claims about Kant.

${ }^{8}$ The distinction between theocentric and anthropocentric perspectives is crucial in Henry E. Allison's interpretation of Kant's transcendental idealism. See Allison, Kant's T ransendental Idealism: A n Interpretation and D efense - a Revised and E nlarged E dition (New Haven, CT and London: Yale University Press, 2004; 1st ed. 1983), chapter 2.

${ }^{9}$ We could list a number of cases, taken from various fields and discourses of philosophy, where a transcendental-pragmatist approach, drawing from sources such as Kant and transcendental philosophy, Wittgenstein, and pragmatism (especially William James), can be contrasted with the dead-ends of mainstream analytic philosophy. The various forms of this approach share the opposition to metaphysical realism and its theocentric perspective, emphasizing the anthropocentric perspective and its human relevance (though also rejecting, at the other extreme, postmodernist relativism and radical constructivism). This opposition can be manifested (in addition to the topic of this essay) in, e.g., (i) general ontology/ metaphysics, especially the realism discussion, as the difference between Aristotelian and Kantian approaches; (ii) the philosophy of mind, as the division between mainstream naturalisms and materialisms on the one hand and theories of transcendental subjectivity on the other; (iii) ethics and metaethics, as the tension between moral (anti)realism (as well as applied ethics) and moral reflections on human finitude and meaning avoiding any neat theory vs. practice division; (iv) the philosophy of relicion, as the opposition between the analytic discourse on theism vs. atheism, the metaphysics of G od, Christian philosophy, evidentialism, etc., and pragmatist approaches to religious belief; (v) the philosophical discourse on evil and suffering, as the conflict between theodicism and antitheodicism; and (vi) metaphilosophy (implicitly exemplified by this paper, too), as the concern with the need to choose between these rival philosophical methodologies. Many of these problem areas, especially (ii) and (iv), are related to "special metaphysics" (in contrast to "general metaphysics"), and it is these issues concerning the soul (and its mortality or immortality), freedom, and God that Kant - who discussed these themes in the transcendental dialectic and again as postulates of practical reason in his moral philosophy - regarded as "what is really at stake" in philosophy. Moreover, we might say, from a Kantian perspective, that ethics guides this entire approach; practical reason is primary to theoretical reason in the sense of forcing us the kind of oppositions centering around the issue of human relevance. This could also be interestingly connected with James's employment of the pragmatic method. (Cf., e.g., Sami Pihlström, Pragmatist M etaphysics: A n E ssay on the E thical G rounds of 0 ntology [London: Continuum, 2009]; and Pihlström, Pragmatic Pluralism and the Problem of G od [New Y ork: Fordham University Press, 2013]..)

10 Ludwig Wittgenstein, Tractatus L ogico-Philosophiaus (1921), trans. B.F. McG uinness and D .F. Pears (London: Routledge and Kegan Paul, 1974), §5.641.

11 The mortal, vulnerable other is the center of Levinas's entire philosophical work; see, e.g., Emmanuel Levinas, Totality and Infinity: A n E ssay on E x teriority, trans. Alphonso Lingis (Pittsburg, PA: D uquesne University Press, 1974; French original 1961). I will shortly get back to the solipsism issue in relation to J.J. Valberg's work.

12 See Wittgenstein, Tractatus, §§6.43-6.4311.

${ }^{13}$ See J.J. Valberg, D ream, D eath, and the Self (Princeton, NJ: Princeton University Press, 2007); Mark Johnston, Surviving D eath (Princeton, NJ: Princeton University Press, 2010). Notably, both are neglected by Luper in his encyclopedia entry "D eath". I am here referring to these contributions briefly and inconclusively; I cannot do justice to the richness of their discussions. See, however, Pihlström, D eath and Finitude (cited above), for further discussion.

14 Valberg, D ream, D eath, and the Self, 11.

15 Ibid., 12 . See also 96-97, $185 f f$.

16 Ibid., 129.

17 Ibid., 144.

18 Ibid., 178

19 Ibid., 179. The absence of what Valberg calls THIS is NOTHINGNE SS, there being no horizon. Puzzlingly, even then, the world "would still be there, just as it is", but "it would not be present" (ibid., 180). A Wittgensteinian-like interplay between solipsism and realism seems to be at work here.

20 Ibid., 185.

21 Ibid., 182.

22 Ibid., 186; also 484. Elsewhere, he points out that becoming open to the truth of solipsism is making a philosophical discovery (ibid., 205), responding to a challenge of self-understanding (cf. ibid., 234).

23 Ibid., 187.

${ }^{24}$ Ibid., 189. The solipsism at work here is (as Valberg notes; ibid., 186) very different from the naive epistemological solipsism that philosophers like Russell addressed (see Bertrand Russell, H uman Knowledge [New Y ork: Simon \& Schuster, 1948]); such solipsism hardly deserves serious philosophical attention.

25 Valberg, D ream, D eath, and the Self, 198.

${ }^{26}$ Ibid., 207.

27 Ibid., $215 f f$.

28 Ibid., 227-228; see also 482-483.

29 Ibid., 232.

30 Ibid., $403 f f$. especially 407.

31 See Johnston, Surviving D eath, 168-169.

${ }^{32} \mathrm{Cf}$. the critical discussion of Wittgenstein's Tradatus in ibid., 182-183, and of Valberg at 184-185. 
${ }^{33} \mathrm{Cf}$. ibid., 225 - though, in a Wittgensteinian vein, the idea of dealing with objects, intentional or not, here is misleading.

34 Ibid., 222.

35 Ibid., 230-231.

36 Ibid., 236.

37 Valberg, D ream, D eath, and the Self, 262.

38 This paradoxical character of human subjectivity is analyzed in a transcendental manner in David Carr, The Paradox of Subjectivity: The Seff in the Transcendental Tradition (O xford: O xford University Press, 1999). For further discussions, see again Pihlström, D eath and Finitude, especially chapter 3.

39 Wittgenstein, Tractatus, §5.64.

${ }^{40}$ Valberg, D ream, D eath, and the Self, 224.

${ }^{41}$ See again Carr, The Paradox of Subjectivity.

42 For a reading of the Tradatus as a Kantian-like synthesis of transcendental solipsism and empirical realism, see Heikki Kannisto, Thoughts and Their Subject: A Study of W ittgenstein's Tractatus (A da Philosophica F ennica 40, Helsinki: The Philosophical Society of Finland, 1986).

${ }^{43}$ See D .Z. Phillips, "Dislocating the Soul", Religious Studies 31 (1995), 447-462. Mikel Burley offers an illuminating critical reading of Phillips in relation to Wittgenstein in Burley, Contemplating Religious Forms of Life: Wittgenstein and D.Z. Phillips (Basingstoke: Palgrave, 2012). Phillips would never accept the characterization of his views as transcendental (or pragmatist, for that matter).

${ }_{44}$ Supernaturalism is, for Phillips, irrelevant and misleading in a sense different from the sense in which it is irrelevant and misleading according to Johnston (see Surviving D eath). This is because Johnston, while criticizing supernaturalism on moral grounds, still operates in terms of metaphysical realism.

45 Phillips, "D islocating the Soul", 450, 452, 455; cf. Burley, Contemplating Religious Forms of L ife, chapter 5. Phillips's seminal statement of his view that immortality must not be thought of as the temporal existence of a disembodied spirit after the death of the body but rather as "dying to oneself" can be found in D.Z. Phillips, D eath and Immortality (London: Macmillan, 1970), 51-54.

46 Phillips, "Dislocating the Soul" , 453.

47 Ibid., 455.

48 The latter is something we find in Kant as well, in the form of the immortality of the soul as one among the postulates of practical reason.

49 Ibid., 458.

50 Ibid., 460.

51 Phillips, W ittgenstein and Religion, xiii; see also xx. Compare xi: "[i]t is only in the context of [religious] language games that belief in God has any meaning".

52 See Valberg, D ream, D eath, and the Self, 485. 